\title{
Human Enhancement and the Giftedness of Life
}

Professor Michael Hauskeller, Associate Professor

University of Exeter, Department of Sociology and Philosophy, Amory Building, Rennes Drive, Exeter EX4 4RJ

Email: m.hauskeller@exeter.ac.uk 


\section{Human Enhancement and the Giftedness of Life}

Abstract:

Michael Sandel's opposition to the project of human enhancement is based on an argument that centres on the notion of giftedness. Sandel claims that by trying to 'make better people' we fall prey to, and encourage, an attitude of mastery and thus loose, or diminish, our appreciation of the giftedness of life. Sandel's position and the underlying argument have been much criticised. In this paper I will try to make sense of Sandel's reasoning and give an account of giftedness that, if possible, defends its relevance for the ethical assessment of the human enhancement project. In order to do so, I will also look at virtue-related notions, such as gratitude and humility, and distinguish the gifted from the merely given. The failure to acknowledge this distinction gives rise to one of the most common objections to Sandel's argument. Other objections will be shown to rest on similar misunderstandings.

Key words:

Giftedness, Gratitude, Human Enhancement, Humility, Transhumanism 


\section{Human Enhancement and the Giftedness of Life}

"Gratitude is the sign of noble souls."

Aesop, Androcles and the Lion

An increasing number of philosophers and scientists argue that we should use (or should at least not be prevented from using) biotechnology to enhance human nature in every possible way. ${ }^{1}$ However, some obstinately believe that we should not. To justify their scepticism, those 'bio-conservatives', as they are derisively dubbed by their melioristic opponents, have brought forward various arguments, none of which has been found compelling by those who advocate human enhancement. In this article I want to look at one particular argument and the notion that forms its backbone. The argument was proposed by Michael Sandel, first in a short paper entitled "The Case Against Perfection", which was published in the Atlantic Monthly in 2004 and most recently in a book bearing the same title. ${ }^{2}$ The notion at the core of the argument is that of 'giftedness'.

Sandel's argument

Sandel discusses the case of an athlete who excels in their chosen sport not as a result of extensive training and effort but because of drugs and genetic amendments. Sandel

\footnotetext{
${ }^{1}$ E.g. John Harris, Enhancing Evolution, Princeton and Oxford: Princeton University Press 2007; Julian Savulescu, 'Procreative Beneficence: Why we should select the best children', Bioethics 15/5,6 (2001): 413-426; Nick Bostrom, 'Why I Want to be a Posthuman When I Grow Up', in Medical Enhancement and Posthumanity, eds. Bert Gordijn and Ruth Chadwick, New York, Berlin: Springer 2008, 107-136; Nicholas Agar, Liberal Eugenics, Oxford: Blackwell 2004; Gregory Stock, Redesigning Humans, London: Profile Bocks 2003.

${ }^{2}$ Michael Sandel, 'The Case Against Perfection', The Atlantic Monthly 293/3 (2004); Michael Sandel, The Case Against Perfection, Cambridge, Mass., London: The Belknap Press of Harvard University Press 2007.
} 
claims that such an athlete's success would not be their success at all. If there is achievement here it belongs to those who invented the drugs or the relevant enhancement technology. The athlete ceases to be an agent and becomes a mere machine programmed by others. Sandel believes that this is a problem, but he also believes that it is not the main one. Beside effort, there is an at least equally (if not more) important second aspect to the athletic ideal, namely (the display and cultivation of) gift. And this is an aspect that according to Sandel ought to be preserved, not only in competitive sport but generally as an object of experience and appreciation. Here is Sandel's argument in his own words:

The deeper danger is that they (i.e., enhancement and genetic engineering) represent a kind of hyperagency, a Promethean aspiration to remake nature, including human nature, to serve our purposes and satisfy our desires. The problem is not the drift to mechanism but the drive to mastery. And what the drive to mastery misses, and may even destroy, is an appreciation of the gifted character of human powers and achievements. To acknowledge the giftedness of life is to recognize that our talents and powers are not wholly our own doing, nor even fully ours, despite the efforts we expend to develop and to exercise them. It is also to recognize that not everything in the world is open to any use we may desire or devise. An appreciation of the giftedness of life constrains the Promethean project and conduces to a certain humility. ${ }^{3}$

Now what exactly is Sandel saying here? Admittedly, his argument is not entirely clear, but I take him to mean roughly the following: human enhancement (particularly, but not exclusively, genetic enhancement) is morally wrong because it is dangerous, and it is dangerous because, or insofar as, it represents hyperagency, that is the aspiration to remake nature in such a way that it serves our purposes and satisfies our desires (even more than it already does), or, in short, the drive to mastery.

\footnotetext{
${ }^{3}$ Sandel 2007, 26-27.
} 
The use of the term 'represent' is perhaps slightly misleading in this context since although it might be plausibly argued that genetic enhancement is a paradigmatic case of hyperagency or of acting out the drive to mastery, and insofar is particularly apt to represent, or stand for, hyperagency in general, it is obviously not this representational aspect that makes it dangerous. The danger must lie somewhere else, namely in the fact that the attempt to enhance humankind as a whole is an expression or embodiment of the drive to mastery. This is what I take Sandel to mean here. When we are trying to remake nature, then we are following this drive (whether or not this is what motivates our actions) and thus affirm and very likely reinforce it. The drive to mastery lies no longer dormant or within, comparatively restrained by natural boundaries, but has found a powerful vehicle that supports and accelerates its spread. If this interpretation of Sandel's argument is correct, then the reason for not pursuing human enhancement is that we shouldn't give in to and thereby encourage and assist the drive to mastery. But why shouldn't we? What is wrong with the drive to mastery? Sandel gives an answer which leads the argument to its apparent conclusion. We shouldn't follow this drive because, he says, by doing so we lose "an appreciation of the gifted character of human powers and achievements". Instead of aspiring to remake nature we should rather recognize that "our talents and powers are not wholly our own doing" and that "not everything in the world is open to any use we may desire or devise". This is what acknowledging the "giftedness of life" means. If we do acknowledge it, the drive to mastery gives way to a "certain humility". And that, we may add, is good, whereas not having this humility is bad. But is it really?

Frankly, this whole train of reasoning doesn't sound like a conclusive argument at all. Of course it can hardly be contested that, as Sandel says, "our talents and powers are not wholly our own doing". Even though we may choose to develop 
certain natural talents and let others lie idle so that the powers we gain through practice owe their existence to a large degree to our choices and efforts, there must be something given on which to build up. I cannot choose to become a great musician or novelist, no matter how much I am prepared to work for it, though there probably are people who might have become great musicians or novelists if only they had properly nurtured their talents. Normally, at least our talents (if not our powers) are beyond our control. However, genetic engineering might help us change this and induce talents that we would not have had otherwise. Even though our talents and powers are not wholly our own doing now, they may well be in the future when enhancement techniques are universally available and routinely used. After all, that seems to be the whole point of human enhancement: to become able to choose what we are. Yet even then, Sandel could point out, something must always remain given. If nothing were given there would be no ground from which to make a choice. If I want to give myself a certain talent, I have to employ certain capacities. I must be able to want this talent, to correctly judge the desirability of it, and finally to bring it about. In other words, it requires talent to create talent. So our talents and powers really are never wholly our own doing and never will be. But what follows from that? Why should this be a reason not to undertake the deliberate creation of talents and powers? Sandel says that acknowledging the giftedness of life also means recognizing that "not everything in the world is open to any use we may desire or devise". Is this meant to be a descriptive or a prescriptive statement? Taken as a descriptive statement it does not tell us anything about whether or not we should pursue human enhancement. Perhaps there are things that we will never be able to use at our will. But if that is so we need not be concerned about these things. What cannot be done cannot be done, and the question whether we ought to do it simply does not arise. If, on the other hand, the 
statement is prescriptive and means that there are some things in the world that we ought not to subject to any use we may desire or devise, then it is unclear on what grounds this claim rests. Presumably those things that we ought not to use any way we please are our talents and powers, the reason being apparently that they are not "wholly our own doing". But clearly the fact that our talents and powers are not wholly our own doing does not warrant the conclusion that we should abstain from manipulating and changing them. So again, what exactly is Sandel's argument?

Well, for one thing we can safely say that he is trying to introduce a new perspective to the discussion of human enhancement. Usually the discussion focuses on the question whether what is thought to be an improvement of human nature might not, at the end of the day, turn out to have severely damaged it. As it is commonly framed, the question is whether a particular kind of enhancement, e.g. memory enhancement or the extension of human life span, will really benefit those who are subjected to it. Would they really be better off than we are now? Perhaps they would lose more than they would gain. Sandel, however, is concerned not so much with the harm that we might inflict on the supposedly enhanced, but rather with the harm that we might inflict on ourselves. Enhancement, for Sandel, is not primarily wrong because it harms the enhanced but rather because it harms the enhancers. When A enhances B, B might not be harmed at all, but A always is, and that is why it is always wrong to attempt to enhance someone (even ourselves). And why are the enhancers harmed even when the enhanced are not? Because they allow their inherent drive to mastery to reign and all humility to disappear. For Sandel, humility is a virtue, and virtue is what the whole argument seems to be about.

\section{Humility and giftedness}


If we all agreed that humility was a virtue and that the attempt to make better people was detrimental to humility, then we would have at least a prima facie reason to oppose human enhancement. It is only a prima facie reason because we might decide that although humility is a good thing, there are other things that are even better, so that if we can gain the latter by sacrificing the former we should do it. But of course humility is far from being generally accepted as a virtue today. It is reputed to be a decidedly Christian virtue, which has no place in a modern, enlightened society. Being humble traditionally means to know that one's power is very limited, that there are others who are far cleverer and more talented than ourselves, and finally and most importantly that all human power is negligible compared to the power of God. An attitude such as this does not exactly encourage the transgression of boundaries. Consequently, those who advocate human enhancement tend to echo Nietzsche and deny that there is any special worth in humility. "I personally do not regard humility as a virtue", writes John Harris curtly, ${ }^{4}$ and Max More goes even further by denouncing humility as a false virtue invented by the Church to keep humanity at bay and to prevent any progress: "Apart from the sheer falsity and irrationality of religion it has had the unfortunate consequence (...) of debasing humanity. By inventing a God or gods and elevating them above us, by making external divinity the source of meaning and value, and by abasing ourselves before these higher powers, we have stifled our own emerging sense of personal value. We can look up while on our knees, but we cannot walk forward." So is that what Sandel wants us to do - fall back on our knees and thus dispense with standing upright and walking forward? Sandel does not talk about God, though. Instead, he talks about the giftedness of life, about powers

\footnotetext{
${ }^{4}$ Harris 2007, 113.

${ }^{5}$ Max More, 'Transhumanism. Towards a Futurist Philosophy', accessible from More's website www.maxmore.com/transhum.htm
} 
and talents that are not wholly our own doing. We are not asked (or advised) to be humble in the face of God's absolute power, but rather in the face of that dark ground of our own being, by virtue of which we are what we are, which then in turn allows us to aspire for something better. And being humble means to appreciate this and not try to interfere with it. But is there any reason why we should be humble in the absence of religious belief? It seems that for there to be such a reason some good must result from it, but so far it is unclear what this good might consist in.

Even Leon Kass, who shares Sandel's scepticism with regard to human enhancement, thinks that the notion of giftedness is not very helpful. The giftedness of nature, he points out, "also includes smallpox and malaria, cancer and Alzheimer's disease, decline and decay." "Modesty born of gratitude for the world's 'givenness' may enable us to recognize that not everything in the world is open to any use we may desire or devise, but it will not by itself teach us which things can be fiddled with and which should be left inviolate. The mere 'giftedness' of things cannot tell us which gifts are to be accepted as is, which are to be improved through use or training, which are to be housebroken through self-command or medication, and which opposed like the plague." According to Kass, the fact that something is 'given' does not tell us anything; what we have to ask ourselves is rather whether there is something precious in what has been given to us. ${ }^{7}$ John Harris ${ }^{8}$ makes the same point and agrees (for once) with Kass that what we have been given is not necessarily good, and only what is good should be taken into account, morally speaking. So it seems that Sandel's argument from humility and the giftedness of life is very weak indeed.

However, neither Harris nor Kass properly distinguish between the 'given' and the 'gifted' and they both overlook the special connotations of the latter. Being

\footnotetext{
${ }^{6}$ Leon Kass, 'Ageless Bodies, Happy Souls’, The New Atlantis 1 (2003): 9-28.

${ }^{7}$ Kass 2003, 20.

${ }^{8}$ Harris 2007, 112-3.
} 
gifted means that one has received (natural) gifts. A gift is not merely something given. Anything can be given, but not just any old thing can be a gift. There are various features that distinguish the gift from the merely given. First of all, a gift is something that has been given to us as a good. If someone has given it to us, then it must at least have been intended to benefit us. Otherwise it would be no gift at all. If you give me a load of rubbish, I will hardly consider it a gift, even if I get it for my birthday (unless, of course, I like rubbish, but then it is no longer rubbish to me). I may, however, be the receiver of something that has not been given to me by anyone in particular. I can then still regard it as a gift, but only if it really is good or at least appears good to me. For this reason, disease or the proneness to disease may be given (though usually not given by someone), but would not normally be considered a gift (although it could be under certain circumstances, namely if the bearer of the disease benefits from it, for instance by reminding them what is really important in life) $)^{9}$. A healthy body, on the other hand, can be considered a gift, because for one thing it has been given to us (in the sense that there is only so much we can do ourselves to make and keep it healthy) and for another because it is a good thing to have.

Secondly, a gift cannot be demanded, acquired, or earned. There is no right to be given a gift. A gift is something that could just as well not have been given. A gift can be something unexpected, and it is always undeserved, or non-deserved. Thus understood, we don't always appreciate health, or even life itself, as a gift. Often enough we feel, on the contrary and with no good reason, that we deserve all the good things in life, those we have got and those we have not. If we fail to gain enough good things or if they are denied to us, we tend to feel that life is treating us unfairly. We

\footnotetext{
${ }^{9}$ Precisely for this reason, the actor Michael J. Fox who suffers from Parkinson's disease describes his apparent misfortune as a "gift" in his memoir Lucky Man (New York: Hyperion 2003). Similarly, the American writer Flannery O'Connor came to see the early death of her beloved father as an expression of God's grace, "like a bullet in the side". Cf. Brad Gooch, Flannery: A Life of Flannery O'Connor, London: Little, Brown \& Co. 2009.
} 
protest that we deserve better. This very common, but actually deeply metaphysical notion is expressed quite well by the renowned transhumanist Nick Bostrom. Bostrom thinks it quite likely that we will "in this century master technologies that will enable us to overcome many of our current biological limitations" and thus "get the opportunity to truly grow up and experience life as it should have been all along". ${ }^{10}$ That life should have been much better than it has hitherto been for anybody at any time is an odd claim that only makes sense within a normative framework that provides for some kind of natural right to happiness. But of course there is no such right, or at least it is very difficult to see whereupon such a right should be based. The truth is that we are neither here to be happy nor, as Arthur Schopenhauer believed ${ }^{11}$, to be unhappy (thus deserving all the suffering we have to endure during our lives). If, on the other hand, we do not believe in such a right, if we do not believe that we have deserved everything good that we've got (but not the bad!), and more, then everything good that actually does happen to us is experienced as a gift.

Thirdly, a gift is not a loan. A loan has to be returned to the lender. A gift, on the other hand, has to be accepted and kept. It must not be returned to the giver, and can only be returned at the risk of insulting them. That does not mean that a gift is entirely free in the sense that it doesn't put the recipient of the gift under any obligation. One has to take good care of the gifts one has received, cherish them, even if one doesn't like them very much. If a gift is given to you and you toss it in the bin, arguing that it's yours and you can do with what is yours whatever you like, then you have misunderstood the nature of the gift. Also, in many societies each gift requires a corresponding gift in return. ${ }^{12}$ Every gift creates an obligation, but it's a curious, informal kind of obligation, because just as you had no right to the gift in the first

\footnotetext{
${ }^{10}$ Nick Bostrom's homepage (http://www.nickbostrom.com), accessed 20/10/2007, since then changed.

${ }^{11}$ Arthur Schopenhauer, The World as Will and Representation II, ch. 49.

${ }^{12}$ Marcel Mauss, The Gift, London/ New York: W.W. Norton 1990.
} 
place, the giver has no right to receive something in return, not even gratitude. ${ }^{13}$ To demand that the gift be reciprocated devalues the gift and in fact negates it by turning it into a business transaction.

Because the gift is given freely, it is (or should be) received with gratitude (despite there being no right to gratitude). In contrast, when we receive only what we deserve, or think we deserve, we don't feel any gratitude at all. If the gift is reciprocated (usually ${ }^{14}$ not immediately, for that too may be regarded tantamount to a denial of the gift, but after a considerable lapse of time) it again appears not as the fulfilment of an obligation, as something that had to be done, but as a free act of goodwill, so it may again elicit gratitude. So in this peculiar relation, when I give something to you and you give something to me we can both be grateful to each other, which of course is not the case in a commercial transaction. When I enter a shop, hand over a certain amount of money to the shop attendant and receive some commodity from him in return, we may verbally thank each other, but in fact neither of us will feel particularly grateful to the other. ${ }^{15}$ And because we don't, the transaction has created no particular social bond between us, whereas exchanging gifts, by inducing mutual gratitude, does create such a bond. ${ }^{16}$

The most remarkable aspect of the gift-specific obligation, which lifts it clearly above any commercial transaction, is that although the gift ought to be reciprocated, it need not necessarily be returned to the one who gave it. We do, for instance, spend lots of love, care, energy, time, and money on our children, and on the

\footnotetext{
${ }^{13}$ Cf. Daniel Lyons, 'The Odd Debt of Gratitude', Analysis 29 (1969): 92-97.

${ }^{14}$ The exchange of gifts at Christmas is a remarkable exception.

${ }^{15}$ There are exceptions, of course. The owner of a small local shop may feel grateful to his customers for continuing to buy at his shop and not at the new superstore nearby, and the customers may feel grateful to the shop owner for providing a valuable service to the community despite the meagre income it generates. In both cases, however, gratitude is appropriate precisely because what is received in exchange for what is given is appreciated as being more valuable than what one has given and hence as a gift that could just as well be withheld.

${ }^{16}$ Cf. Jacques T. Godbout, The World of the Gift, Montreal \& Kingston/ London/ Ithaca: McGillQueen's University Press 1998, 7.
} 
whole give them much more than they will ever be willing or able to return. But if they do appreciate the gift, they may well try to give some of it back to their own children. Similarly, blood and organ donors, or people who give to charities, usually do not give because they have received anything from those (in most cases anonymous people) they are giving to. But in spite of this, they are frequently motivated by a sense of gratitude, a feeling that they have received plenty of good, without particularly deserving it. ${ }^{17}$ As a result, they want to give back some of what they have received. The psychoanalyst and child psychologist Melanie Klein, who believed that for the development of a healthy mind it was crucial to provide the infant with opportunities for enjoyment and thus constitute a sense of gratitude as early as possible, once remarked that gratitude "is closely bound up with generosity. Inner wealth derives from having assimilated the good object so that the individual becomes able to share its gifts with others. This makes it possible to introject a more friendly world." 18 Charity springs from gratitude, and not a gratitude that is directed to a particular person, but rather an unspecific gratitude that is directed towards the world in general. If, on the other hand, someone believes that everything they have is wholly their own doing, they won't have any reason to feel gratitude, and without gratitude no reason to help others. Thus a lively appreciation of the giftedness of life and the ensuing sense of gratitude appear to be prerequisites to the kind of human bonding that transcends the casual relationships of mere economic exchange. ${ }^{19}$ And if that appreciation is what humility means, then the latter is a virtue precisely because it is at the heart of all human solidarity. This is also recognized by Sandel himself:

\footnotetext{
${ }^{17}$ Cf. Richard Titmuss, The Gift Relationship: From Human Blood to Social Policy, London: Allen and Unwin 1970; Robert G. Simmons/ Susan D. Klein/ Richard L. Simmons, The Gift of Life: The Social and Psychological Impact of Organ Transplantation, New York: John Wiley 1977.

${ }^{18}$ Melanie Klein, Envy and Gratitude, London: Routledge/Tavistock 1957, 19.

${ }^{19}$ Cf. Fred R. Berger, 'Gratitude', Ethics 85/4 (1975): 298-309, 305: “the practices associated with gratitude are a manifestation of, and serve to strengthen, the bonds of moral community - the sharing of a common moral life based on respect for each person as having value in himself."
} 
"Here, then, is the connection between solidarity and giftedness: A lively sense of the contingency of our gifts - an awareness that none of us is wholly responsible for his or her success - saves a meritocratic society from sliding into the smug assumption that success is the crown of virtue, that the rich are rich because they are more deserving than the poor." 20

\section{The naturalistic conception of gratitude}

Now it might be objected that the whole notion of the many good things in life that "are not wholly our own doing", and indeed of life itself, ${ }^{21}$ as gifts tacitly presumes the existence of some kind of God. It stands to reason, or so it seems, that there can be no gift without a giver, that is, an agent to whose deliberate action one owes the good one has received. So who is it that has given us life, health, talents and powers? It is not really our parents because they merely initiated a process over which they had little, if any control. Neither can it be nature, unless we think of it as Nature with, as it were, a capital $\mathrm{N}$, that is, a purposeful, quasi-divine agent. If we do not believe in some kind of God and hence in the existence of a divine giver, then it doesn't seem to make sense to speak of the goods we receive from no one in particular as gifts, except in a loose metaphorical sense, so as to express our feeling of appreciation for what we have received without our own doing. Perhaps we can, without making illicit assumptions, appreciate the natural goods as goods, but we cannot reasonably feel grateful for them without presupposing the existence of God. So is Sandel's conception of giftedness too religious to be taken seriously as an essential part of a

\footnotetext{
${ }^{20}$ Sandel 2007, 91.

${ }^{21}$ Godbout (1998, 39-40) describes birth as "a definitive giving of the self, the gift of life, the original gift, which inscribes the gift relationship and its concomitant state of indebtedness in every individual (...). The chain of gifts begins here for everyone, in a debt that can only be discharged by giving life in one's turn, establishing the fundamentally non-dyadic, asymmetrical character of the gift itself."
} 
secular philosophical argument? Sandel himself denies this, ${ }^{22}$ and I think with good reason. Gratitude is not primarily an emotion that is directed towards a particular person. We can feel gratitude in various situations and for various things. We can be grateful for the love we have found, for being healthy, for our children and their being healthy, and for having a job we like to do (or, at times like this, having a job at all). We can be grateful for having a body with organs that, among many other things, can, when we enjoy, say, a day at the seaside, see the sun set over the sea, feel the waves breaking cold against our skin, hear the seagulls cry, and smell the air filled with the rich fragrance of salt, algae and decaying sea creatures. We can be grateful that we are still able to walk and that we've been able to walk in the first place. And if we can not, there are still innumerable other things for which we can be grateful, not the least of which is our being alive. In none of these cases are we grateful to anybody in particular, not even to God. In fact, we don't even have to believe there is a God. We may still be grateful. We may even be grateful for not believing in God. The (particularly in the USA) popular bumper sticker slogan “Thank God I'm an atheist!”, which is sometimes attributed to the eminent evolutionary biologist J.B.S. Haldane, is on the surface a performative contradiction, but in truth only the paradoxical expression of a widespread sentiment of non-personal gratitude (as well as, of course, a political provocation). God functions here merely as a placeholder, a concession to the grammar, but not the essence, of gratitude. We are grateful without religious beliefs, simply because we know we haven't earned any of this, and none of it was due to us. Instead, we know we have simply been lucky (and some of us feel lucky and hence grateful that we have not fallen for what Richard Dawkins recently called

\footnotetext{
${ }^{22}$ Sandel 2007, 93.
} 
the "God Delusion"23). On the other hand, GK Chesterton may have had a point when he, citing Rosetti, remarked that "the worst moment for the atheist is when he is really thankful and has nobody to thank." ${ }^{24}$ But even this is an acknowledgement that one can be thankful in the absence of anyone in particular to thank. ${ }^{25}$

In this vein, Robert Solomon argues for what he calls a naturalistic conception of gratitude in his book Spirituality for the Sceptic ${ }^{26}$. Solomon believes that the nonpersonal kind of gratitude that I have just described "is an extension of our more usual, interpersonal emotion. In this case it is the emotion and not the specificity of its object that ultimately determines its meaning. Whether or not there is sufficient personification of fate to warrant personal thanks, the recognition of fate in any sense implies that we are the beneficiaries of good fortune in a cruel universe. This should dictate gratitude, even if there is no one or nothing in particular to whom that gratitude is directed." 27 And he continues: "It is also odd and unfortunate that we take the blessings of life for granted - or insist that we deserve them - then take special offense at the bad things in life, as if we could not possibly deserve those. (...) Whether or not there is a God or there are gods to be thanked, however, seems not the issue to me. It is the importance and the significance of being thankful, to whomever or whatever, for life itself. (...) We might say that one is grateful not only for one's life but to one's life - or rather to life - as well." 28

I agree mostly with Solomon's account. However, it seems to me that, by describing non-personal gratitude as an extension of interpersonal gratitude, he grants

\footnotetext{
${ }^{23}$ Richard Dawkins, The God Delusion, London: Bantam Books 2006.

${ }^{24}$ Gilbert Keith Chesterton, St. Francis of Assisi, London: Hodder and Stoughton 1923, 88

${ }^{25}$ Perhaps God can be reinstated as a regulatory idea in Kant's sense, never to be known, but subjectively necessary to make sense of our gratitude.

${ }^{26}$ Robert C. Solomon, Spirituality for the Skeptic. The Thoughtful Love of Life, New York: Oxford University Press 2002.

${ }^{27}$ Solomon 2002, 104.

${ }^{28}$ Solomon 2002, 105.
} 
too much to those who insist that only the latter is gratitude proper. In fact, nonpersonal gratitude is much more common, and much more basic, than interpersonal gratitude. Of course, sometimes we are grateful to particular people, for what they have done for us. But that is rather the exception. And it certainly does not define our sense of gratitude. That is to say that this kind of situation is not where we have learned to feel grateful or how to feel grateful, nor what gratitude really means. We do not first experience gratitude in these interpersonal cases and then later transfer this feeling to situations where there is no one in particular to be grateful to. It is in fact the other way round. If we had never experienced the feeling of gratitude in relation to the gifts of life, we would not be able to feel it with respect to another person because we would not be able to appreciate what they have given us. It has been objected to me that children acquire the concept of gratitude by being taught to say 'thank you'. This may well be, but the concept of gratitude is not the issue, the feeling is, or the attitude that accompanies it. We do, of course, teach our children to say 'thank you', but that is obviously not the same as teaching them actually to be grateful. Notoriously, parents fail to teach their children that. Surely we can learn to say 'thank you' when it is expected or appropriate without really meaning it. In order to mean it, that is to actually feel gratitude, we need to appreciate what is being given to us as an undeserved good. So how do we learn that what we get is not ours by rights, that we could just as well have not received it, that, in other words, it is a gift? I'm not sure if something like that can be taught at all (How are the virtues taught? asked Socrates, and despite all his searching couldn't find an answer). I suspect that we have either got it in us to appreciate life and the good things in life as gifts, or we don't. If we do, we will feel grateful for what we've got and what we receive, no matter whether someone gives it to us or not. However, only if we do will we be able to feel gratitude when 
someone does something for us that they didn't have to do. There is no reason to believe that children first need to learn to say 'thank you', that is to participate in a social ritual, before they can acquire a sense of gratitude. As far as I can see, there is no causal or logical connection between the social act and the feeling. Of course it is hard to imagine a community of humans who are grateful to the universe, but not to their fellow humans when they receive a gift from them. I wouldn't say it is logically impossible, but it's probably psychologically impossible. But this impossibility does not prove that interpersonal gratitude is more basic than what we may call cosmic gratitude. Only if a community were possible whose members felt truly grateful to each other, but never for being alive, or being able to see the beauty of the world, or for anything else that was not given to them by someone, could the derivative nature of non-personal gratitude be shown. But though one may imagine such a community, I don't think that it is in reality possible.

Our gratitude for being alive is not merely a derivative or metaphorical kind of gratitude. It is perfectly real and, moreover, perfectly adequate. "Gratitude recognizes the fact that we are not, in fact, the authors of our own destiny, that we owe our good fortune to others and, perhaps, to luck." ${ }^{29}$ In other words, gratitude recognizes the giftedness of life.

\section{The better is the enemy of the good}

In a little known poem from 1772, Voltaire approvingly cites one "Italian sage" who claimed that "the better is the enemy of the good." taken out of context and misunderstood as a call for constant improvement. It is taken

\footnotetext{
${ }^{29}$ Solomon 2002, 105-6.

${ }^{30}$ Francois-Marie Arouet Voltaire, La Begueule, in: Oevres Completes de Voltaire
} 
to mean that nothing is so good that it cannot be improved upon. The good is only just good enough and in the face of the better not good at all, i.e. not worth preserving. The better is the enemy of the good in the same sense as the good is the enemy of the bad. However, this is not at all what Voltaire intended to say. Although he acknowledges that there is room for improvement with respect to the goodness of our hearts, our talents and our knowledge, he advises caution: Let us not pursue pipe dreams, he says, for happy is he "who stays at his place and guards what he has got" (vivre à sa place, et garder ce qu'il a), thereby echoing his anti-Leibnizian hero Candide's final insight that we must take care of our garden. ${ }^{31}$ To guard what one has got is the practical appreciation of giftedness. (Also to cultivate it, of course, but to cultivate something is not the same as overcoming it and leaving it behind.) The worth of what has been given to us is here acknowledged as an absolute value in the Kantian sense, that is, a value that allows for no comparison. It is not good merely in the absence of something better or in comparison with what is worse. Rather, it is good in it self, absolutely. The better is the enemy of the good in the sense that by confronting the good with the 'better', the good changes its appearance and reemerges as the 'worse'. When we focus on the better that we might achieve, we tend to forget what is good about what we have already got. It is, in other words, an act of conceptual devaluation, which in turn justifies the demand for improvement. Optimism regarding the future has as its flipside pessimism regarding the present. This pessimism may or may not be justified. It all depends on whether we set our hopes on the future because the present actually is found deficient, or we judge it deficient merely because we envisage a (largely imaginary) future that is (in some unspecified sense) better? The way calls for human enhancement are framed often

\footnotetext{
${ }^{31}$ Francois-Marie Arouet Voltaire, Candide, or Optimism, ch. 30
} 
suggests the latter. Nick Bostrom precedes his article 'Why I Want to be a Posthuman when I Grow Up' with a quote from Bishop Berkeley: "I am apt to think, if we knew what it was to be an angel for one hour, we should return to this world, though it were to sit on the brightest throne in it, with vastly more loathing and reluctance than we would now descend into a loathsome dungeon or sepulchre."32 This is to say that this world, no matter how rich and beautiful it may appear to us, lacks all beauty for the angels and is regarded by them only with loathing, and if we could only see what they see we would feel about it exactly like they do. But we do not even have to have angel eyes ourselves to have our view of the world changed. The mere belief that an angelic perspective on the world is possible has already the effect of diminishing our appreciation of the goods that this world has to offer. Bostrom goes on to utilise this effect in the course of his argument for radical enhancement when he imagines what our posthuman future will be like: "You have just celebrated your $170^{\text {th }}$ birthday and you feel stronger than ever. Each day is a joy. You have invented entirely new art forms, which exploit the new kinds of cognitive capacities and sensibilities you have developed. You still listen to music - music that is to Mozart what Mozart is to bad Muzak." 33 So that is what we can look forward to, once we have sufficiently enhanced ourselves: that we will no longer be able to appreciate great art as we know it. Of course, what we consider great art today will be recognized as not being great at all. In the face of the art we are going to create, Mozart's music will appear dull, and so will, say, da Vinci's paintings and Shakespeare's plays. In fact, everything that excites, fascinates and enraptures us today will no longer have any interest to us whatsoever. But can we really believe that what makes Mozart great is entirely comparative, that there is nothing of intrinsic value in his music? Is the only reason

\footnotetext{
32 The Works of George Berkeley, London: G. Bell 1897, 172, quoted from Bostrom 2008, 107.

${ }^{33}$ Bostrom 2008, 112.
} 
we find greatness in some artworks that at present we haven't got anything better? Not only do I find this highly implausible; it also, by rendering all values relative, contravenes the rationale of the whole human enhancement project. For if the things that we regard as good today are only good so long as there is nothing better, if there is nothing of absolute value, then the same holds true for what we will regard good in our posthuman future, and then there is actually no good reason why we should swap our present condition for a posthuman one - unless of course we will, as Bostrom suggests, feel vastly more joy at living our lives than we do now. But will we really? Why should we if we can't seem to find enough joy in our present state of being? Why should we be satisfied then if we are not satisfied now? There will, after all, always be the possibility of something being even better than what we've got.

An appreciation of the giftedness of life includes an appreciation of what is good in what we have got, and good not in a relative, but in an absolute sense. As good in this sense we may regard our own existence, talents and abilities, but also what we find in our natural and human environment: the beauty of nature, the music and books we can enjoy, and much more. Without an appreciation of all this, we cannot be truly happy, because happiness needs to be grounded in some sense of objective good, of doing things that are truly worth our while. What Sandel calls the drive to mastery, whose ultimate end is nothing less than complete control over nature, is an attitude that denies absolute value to all things, including all human achievements. Whatever we may want to point out as good and hence worth preserving, the proponent of radical human enhancement will always feel inclined to reply that it's not nearly good enough: 'That's nothing, we can do better than that' seems to be his general attitude to life. But can we really? And even if we can, is it 
good for us to look at the world with this kind of disparaging attitude, that is, to regard all Mozart as potential Muzak?

\section{Being at Home in the World}

According to Godbout, the "transformation of a stranger into a familiar is what the gift is all about." ${ }^{, 34}$ This is not only true with respect to social relations, but also, I dare say, with respect to our relation to the world as such, to the universe as a whole. Seeing the good in what we've got, i.e., appreciating the giftedness of life, helps us feel at home in the world. It creates a bond, connects us to the rest of the world, which then no longer appears hostile and forbidding, an alien place that may perhaps be best described as enemy territory. The drive to mastery and the denial of giftedness affirm this enmity. They reinforce an almost Manichaean point of view, according to which it's either 'us' (the Promethean, nature-defying, boundary-transgressing, star-reaching human) or 'them' (nature as the evil power that prevents us from rising to the stars where we belong). Taking a stance against nature becomes a matter of survival and of self-affirmation. It is a matter of life and death, of who is going to win and who is going to lose. From that perspective, the physical world is out there to be subjugated and vanquished or else be allowed to subjugate and vanquish us. We are not part of it, and it will eventually destroy us, unless we rebel against nature's tyranny whose foremost expression is the inevitability of death (vividly portrayed in Bostrom's 'Fable of the Dragon Tyrant ${ }^{35}$ ). However, as Bryan Appleyard has rightly pointed out, it "is the fact of loneliness, not death, that is most shocking about our time on earth. By loneliness I mean here the feeling of being disconnected, of having no

\footnotetext{
${ }^{34}$ Godbout 1998, 30.

${ }^{35}$ Nick Bostrom, 'The Fable of the Dragon Tyrant', Journal of Medical Ethics 31/5 (2005): 273-277.
} 
home." ${ }^{36}$ Cultivating a feeling of giftedness and not giving in to the drive to mastery is a remedy to that kind of cosmic loneliness. It reconciles us even to our own mortality by allowing us to identify with the course of nature and thus, as it were, enlarging the self. It creates the same "feeling of unity" that John Stuart Mill hoped would one day make it as natural for us to care for our fellow beings as it is now natural to us to care for ourselves. ${ }^{37}$ To regard one's life as a gift means to regard it as something precious and at the same time something that, precisely because it is so precious, we have a duty to pass on. 'We owe God a death', says the deliberately misnamed brave soldier Feeble in Shakespeare's Henry $I V^{38}$, thereby emphasising, not the worthlessness of human life, but rather the obligation that comes with the reception of a life. And part of that obligation is that we do not cling too fiercely to it, that we give up our lives when we consider this necessary in order to secure a greater good, in the conviction that our own existence is not all that matters. If we regard life as a gift we find ourselves desiring to give something in return. We feel that we have an obligation to fulfil, which we do best by eventually making room for new people to whom we pass on the gift of life. Dying, thus understood, is an act of sharing - of sharing the good that is being alive. By striving for immortality (which takes the drive to mastery to its logical conclusion), we, on the other hand, conspire to keep the world for ourselves. We deny the gift and hence do not feel any obligation to reciprocate. All deals are off. The only thing that ultimately matters is our own existence. As Appleyard observes, to "the immortalists, a future in which they do not exist has become a personal affront." ${ }^{, 39}$ The difference between those who wish to eradicate death, or at least get rid of ageing and the inevitability of death (such as Ray

\footnotetext{
${ }^{36}$ Bryan Appleyard, How to Live Forever or Die Trying, London: Pocket Books 2007, 123.

${ }^{37}$ John Stuart Mill, Utilitarianism, ed. Roger Crisp, Oxford: Oxford University Press 2007, ch. 3, sec. 10 .

${ }^{38}$ William Shakespeare, Henry IV, Part 2, Act 3, Scene 2.

${ }^{39}$ Appleyard, 2007, 30.
} 
Kurzweil $^{40}$, Aubrey de Grey ${ }^{41}$, or John Harris ${ }^{42}$ ) and those who have serious doubts about the wisdom of that specific kind of enhancement (such as Leon Kass ${ }^{43}$, Francis Fukuyama $^{44}$, or Michael Sandel himself) is mainly that the former regard life as such a good thing that they want to keep it for themselves for as long as possible, whereas the latter regard it as such a good thing that they want others to be able to enjoy it too. In other words, what separates them is mainly a different outlook on life, and the role we play in it.

A way of being

However, it may be objected that the indefinite extension of human life span through biomedical advances is only one of many different forms of enhancement that are currently actively pursued or envisaged. And most of them do not seem to be sought for selfish reasons at all. Advocates of radical human enhancement often emphasise that we have a moral obligation to develop and use enhancement technologies in order to increase the happiness or the flourishing of future generations. ${ }^{45}$ In other words, it is other (in many cases not even yet existing) people who are most likely to benefit from the proposed scientific endeavours. So selfishness does not seem to be the issue. Accordingly, Frances $\mathrm{Kamm}^{46}$ has argued that the "desire for mastery", contrary to what Sandel seems to believe, does not normally motivate those promoting human

\footnotetext{
${ }^{40}$ Ray Kurzweil and Terry Grossman, Fantastic Voyage. Live long enough to live forever, New York: Plume 2005.

41 Aubrey de Grey, 'Escape Velocity: why the prospect of human life extension matters now', PLoS Biology 2 (2004): 723-6.

${ }^{42}$ Harris 2007, ?

${ }^{43}$ Leon Kass, L'Chaim and its limits: why not immortality?, First Things 113 (2001): 17-24.

${ }^{44}$ Francis Fukuyama, Our Posthuman Future, New York: Farrar, Straus \& Giroux 2002, 57-71.

${ }^{45}$ Savulescu 2001, Harris 2007.

${ }^{46}$ Frances Kamm, 'What is and is not wrong with Enhancement?' Havard University, KSG Faculty Research Working Paper Series (May 2006), which is a revised and extended version of her earlier paper 'Is there a problem with enhancement?', American Journal of Bioethics 5/3 (2005): 5-14.
} 
enhancement. And even in those few cases where a researcher really was motivated by such a drive to mastery, this would not render the enhancement itself morally impermissible. The motive a person has for their action may be taken into account when it comes to assessing their character but it cannot make the action itself wrong. By seeking mastery, we may perhaps justly be regarded as a "bad type of people"47, but what we do may still be considered proper and good. However, it seems to me that Kamm misunderstands the point of Sandel's argument. Sandel is in fact not trying to answer the question whether or not it is morally permissible to pursue human enhancement. Rather, he questions whether it really is a good idea to do so, whether it will do us any good, and whether we will not loose more than we would gain. He is not saying that it is immoral to seek enhancement, but rather that it is unwise. Neither is he claiming that by giving in to the "drive to mastery" we become a "bad type of people". Again, it is not so much a question of being good or bad in the moral sense, but rather of what makes a good human life. By loosing the sense of giftedness we do not become bad: we become impoverished, we loose something that is important, perhaps even essential for a good human life. ${ }^{48}$ For that, the actual motives people have for promoting and seeking human enhancement are largely irrelevant. I need not be motivated by a drive to mastery in order to fall victim to it. A particular kind of action can be an expression of the drive to mastery without being motivated by it. When Sandel talks about the drive to mastery he is not concerned with a particular vice that befalls individuals, but rather a "habit of mind and way of being" that

\footnotetext{
${ }^{47}$ Kamm 2006, 9.

${ }^{48}$ Cf. Paul F. Camenish, 'Gift and Gratitude in Ethics', The Journal of Religious Ethics 9/1 (1981): 134, 18: "We need, both here and elsewhere, to get beyond seeing morality only as a matter of keeping or breaking laws, of fulfilling or failing to fulfil obligations, on which there is no neutral ground, in which one can always be said to have done the right thing or the wrong thing. We need to see morality also as a question of availing ourselves of or of missing out on invitations, calls, gifts - opportunities which could lead to a richer, fuller life for the agent as well as for others."
} 
pervades the beliefs and practices of a community, society or culture. ${ }^{49}$ Evidently, Kamm does not sufficiently appreciate the difference. Responding to Sandel's claim that without a vivid sense of giftedness human solidarity would all but break down, she comes up with a very practical and seemingly sensible solution: "if having the option to enhance leads many people to improve themselves or others, there will be fewer instances of people who are badly off, hence fewer who require the assistance of others. ${ }^{, 50}$ In other words, there will no longer be any need for solidarity, and hence for an appreciation of giftedness. But for Sandel, solidarity is not a means but an end. It is part of what makes human life worth living. Without solidarity we would glide into a monadic existence, independent perhaps, completely autonomous perhaps, but also very lonely. The "feeling of unity" that Mill valued so highly would be gone.

However, Allen Buchanan has argued that even in a "world replete with biomedical enhancements" there would still be plenty of opportunities for sensing giftedness. ${ }^{51}$ A lack of control, he believes, is an ineradicable part of the human condition, which not "even the most extreme biomedical enhancements" are likely to conquer. Thus, contrary to what Sandel seems to think, there is no danger that we will ever have to face a "giftedness shortage". 52 Yet first of all, it is by no means certain that a lack of control is ineradicable. Many proponents of human enhancement explicitly seek to expand the extent of human control (with the ultimate goal of gaining complete control over nature) and seem to be convinced that this is really possible. If they are wrong, then one of the major reasons for seeking human enhancement has disappeared. And secondly, the question is not really whether there will still be opportunities to experience giftedness, but rather whether our sense of

\footnotetext{
${ }^{49}$ Sandel 2007, 96.

${ }^{50}$ Kamm 2006, 39.

${ }^{51}$ Allen Buchanan, 'Enhancement and the Ethics of Development', 25, Kennedy Institute of Ethics Journal 18/1 (2008): 1-34.

${ }^{52}$ Buchanan 2008, 26.
} 
giftedness will suffer or is already suffering by our trust in the happiness-maximising or control-maximising powers of enhancement technologies. The question is whether the application of such technologies will make us less inclined to appreciate giftedness.

In his latest book, Anthony Appiah remarks that "what we are matters for human flourishing as well as what we $d o "{ }^{53}$ Sandel's emphasis on giftedness is an attempt to remind us that what we do shapes what we are, and vice versa, and that philosophical ethics, instead of seeking solutions to moral or practical conundrums, should pay more attention to questions of existence. ${ }^{54}$ Virtue, I said earlier, is what Sandel's whole argument seems to be about. But virtue understood in an Aristotelian sense as a precondition of the good life. A lively appreciation of giftedness may well be such a precondition.

\footnotetext{
${ }^{53}$ Kwame Anthony Appiah, Experiments in Ethics, Cambridge, MA/ London: Harvard University Press 2008, 64.

${ }^{54}$ Appiah 2008, 198.
} 